\title{
Study on the Killing Effect of Sodium Hypochlorite and Benzalkonium Bromide and the Compatibility of Them with the Scale and Corrosion Inhibitor
}

\author{
Xue-jun Xie ${ }^{1}$,, , Yuan-lin Zhang ${ }^{1}$, Yu Zhang ${ }^{1}$, Hao Fu ${ }^{2}$, Mao-cai Gong ${ }^{2}$, Lin \\ Tian $^{3}$ and Qiang $\mathrm{Fu}^{4}$ \\ ${ }^{1}$ School of Power and mechanical engineering, Wuhan University, Wuhan, China, 430072 \\ ${ }^{2}$ Guodian hanchuan power generation co., LTD, hanchuan, P.R.China, 431614 \\ ${ }^{3}$ Cnooc zhuhai gas power generation co., LTD, Zhuhai, P.R.China, 519050 \\ ${ }^{4}$ Guangdong Power Grid Electric Power Science \& Research Institute, Guangzhou, P.R.China, \\ 510080
}

${ }^{*}$ Corresponding author

Keywords: Sodium Hypochlorite, Benzalkonium Bromide, Killing Effect, Compatibility, Scale Inhibitor, Corrosion Inhibitor.

\begin{abstract}
The killing effect of sodium hypochlorite and benzalkonium bromide and the compatibility of them with the scale and corrosion inhibitor in the seawater is studied in the paper. The research result shows that sodium hypochlorite and benzalkonium bromide have good killing effect, sodium hypochlorite or benzalkonium bromide is not only compatible with a scale inhibitor, also compatible with a corrosion inhibitor formulation.
\end{abstract}

\section{Introduction}

One of the most effective and common method to control microorganism growth in the cooling water system is to add killing agent into the cooling water.

From the investigated market situation, there are many kinds of biocides, most of them are used in the freshwater cooling system, and fewer is aiming at the complex seawater cooling system. Because there are many types of marine organisms in seawater, the higher requirement for the biocide performance is put forward. With the improvement of environmental protection consciousness, the traditional efficient biocide is gradually restricted to be used. In order to balance the environmental protection, economic benefits and the killing effect, the killing method to combine the traditional biocide chlorine with the non oxidizing biocide, such as to combine sodium hypochlorite with quaternary ammonium salt, is chosen. [1-13]

\section{Test Methods}

\section{The Test Method for Killing}

Take 5 reagent bottles of $1000 \mathrm{~mL}, 800 \mathrm{~mL}$ seawater sample and sodium hypochlorite or benzalkonium bromide with different dosage are added in each bottle, and bottles are placed in the water of the constant temperature water-bath at $45^{\circ} \mathrm{C}$. After biocide is added in the seawater, sampling analysis of residual chlorine and bacteria is immediately done, and it is done again after $2 \mathrm{~h}$.After $24 \mathrm{~h}$, sampling analysis of residual chlorine and bacteria should be done and a certain amount of biocide is added in each bottle to make the biocide concentration double, then sampling analysis of residual chlorine and bacteria is done. After $48 \mathrm{~h}$, sampling analysis of residual chlorine and bacteria should be done. 


\section{The Scale Inhibition Effect Test Method of The Scale Inhibitor}

Add the scale inhibitor and biocide with a certain concentration in a certain seawater, and the seawater is condensed to specific multiple. When the seawater is condensed, to observe by macroscope that there is or not water scale formed, water quality is determined to estimate scaling trend of the water sample and compare the scale inhibition effect change of the scale inhibitor before and after the biocide added.

\section{The Inhibition Effect Test Method of the Corrosion Inhibitor}

Add the corrosion inhibitor and biocide with a certain concentration in a certain seawater. When the specimens of carbon steel Q235 are hung in the seawater, to observe by macroscope that the surface of the specimens changes or not. Determine the surface area and the mass of the specimens before and after test, and calculate the corrosion speed and the inhibition efficiency, and compare the inhibition effect change of the corrosion inhibitor before and after the biocide added.

\section{The Water Quality of the Test Seawater}

The test seawater is from Zhuhai cross drain, provided by Guangdong Power Grid Electric Power Science \& Research Institute. The conventional water quality analysis result of the seawater is shown in table 1 .

Table 1. The conventional water quality analysis result of the seawater

\begin{tabular}{|l|l|l|l|l|l|l|l|}
\hline No. & Analysis item & Unit & Result & No. & Analysis item & $\mathrm{Unit}$ & Result \\
\hline 1 & Total solid & $\mathrm{mg} / \mathrm{L}$ & 23210.00 & 17 & $\mathrm{Mg}^{2+}$ & $\mathrm{mg} / \mathrm{L}$ & 750.39 \\
\hline 2 & Dissolved solid & $\mathrm{mg} / \mathrm{L}$ & 22400.00 & 18 & $\mathrm{NH}_{4}{ }^{+}$ & $\mathrm{mg} / \mathrm{L}$ & $<0.10$ \\
\hline 3 & Suspended solid & $\mathrm{mg} / \mathrm{L}$ & 810.00 & 19 & $\mathrm{~F}^{-}$ & $\mathrm{mg} / \mathrm{L}$ & $<0.10$ \\
\hline 4 & Total hardness & $\mathrm{mmol} / \mathrm{L}$ & 40.60 & 20 & $\mathrm{Cl}^{-}$ & $\mathrm{mg} / \mathrm{L}$ & 11525.82 \\
\hline 5 & Carbonate hardness & $\mathrm{mmol} / \mathrm{L}$ & 2.20 & 21 & $\mathrm{NO}_{2}{ }^{-}$ & $\mathrm{mg} / \mathrm{L}$ & $<0.10$ \\
\hline 6 & $\begin{array}{l}\text { Non-carbonate } \\
\text { hardness }\end{array}$ & $\mathrm{mmol} / \mathrm{L}$ & 38.40 & 22 & $\mathrm{NO}_{3}{ }^{-}$ & $\mathrm{mg} / \mathrm{L}$ & 6.10 \\
\hline 7 & Total alkalinity & $\mathrm{mmol} / \mathrm{L}$ & 2.20 & 23 & $\mathrm{SO}_{4}{ }^{2-}$ & $\mathrm{mg} / \mathrm{L}$ & 1694.38 \\
\hline 8 & $\begin{array}{l}\text { ahenolphthalein } \\
\text { alkalinity }\end{array}$ & $\mathrm{mmol} / \mathrm{L}$ & 0.00 & 24 & $\mathrm{PO}_{4}{ }^{3-}$ & $\mathrm{mg} / \mathrm{L}$ & $<0.10$ \\
\hline 9 & Free carbon dioxide & $\mathrm{mg} / \mathrm{L}$ & 12.76 & 25 & $\mathrm{HCO}_{3}^{-}$ & $\mathrm{mg} / \mathrm{L}$ & 134.38 \\
\hline 10 & All silicon & $\mathrm{mg} / \mathrm{L}$ & 2.55 & 26 & $\mathrm{CO}_{3}{ }^{2-}$ & $\mathrm{mg} / \mathrm{L}$ & 0.00 \\
\hline 11 & Activated silica & $\mathrm{mg} / \mathrm{L}$ & 2.49 & 27 & $\mathrm{OH}^{-}$ & $\mathrm{mg} / \mathrm{L}$ & 0.00 \\
\hline 12 & Non-activated silica $^{-}$ & $\mathrm{mg} / \mathrm{L}$ & 0.06 & 28 & $\mathrm{pH}^{-}\left(25^{0} \mathrm{C}\right)$ & $/$ & 7.44 \\
\hline 13 & $\begin{array}{l}\text { Chemical oxygen } \\
\text { demand(COD }\end{array}$ & $\mathrm{mg} / \mathrm{L}$ & 11.78 & 29 & $\mathrm{Total}_{\text {iron }}$ & $\mathrm{mg} / \mathrm{L}$ & 0.12 \\
\hline 14 & $\mathrm{~K}^{+}$ & $\mathrm{mg} / \mathrm{L}$ & 203.57 & 30 & Turbidity & $\mathrm{NTU}$ & 1.56 \\
\hline 15 & Na $^{+}$ & $\mathrm{mg} / \mathrm{L}$ & 6882.43 & 31 & $\begin{array}{l}\text { Electrical } \\
\text { conductivity }\end{array}$ & $\mathrm{ms} / \mathrm{cm}$ & 32.40 \\
\hline 16 & $\mathrm{Ca}^{2+}$ & $\mathrm{mg} / \mathrm{L}$ & 218.07 & & & & \\
\hline
\end{tabular}

\section{The Killing Effect of Sodium Hypochlorite and Benzalkonium Bromide}

The killing effect of sodium hypochlorite or benzalkonium bromide with different dosage is shown in table 2 , and the killing effect of sodium hypochlorite with $8 \mathrm{mg} / \mathrm{L}$ or benzalkonium bromide with $5 \mathrm{mg} / \mathrm{L}$ is shown in table 3. 
Table 2. The killing effect of sodium hypochlorite or benzalkonium bromide with different dosage

\begin{tabular}{|c|c|c|c|c|}
\hline \multirow{2}{*}{ Biocide } & $\begin{array}{c}\text { Concentration } \\
(\mathrm{mg} / \mathrm{L})\end{array}$ & Time $(\mathrm{h})$ & $\begin{array}{c}\text { Residual } \\
\text { chlorine }(\mathrm{mg} / \mathrm{L})\end{array}$ & $\begin{array}{c}\text { Bacterium } \\
\text { number } / \mathrm{mL}\end{array}$ \\
\hline Seawater (blank) & $/$ & $/$ & $/$ & $1.8 \times 10^{6}$ \\
\hline \multirow{5}{*}{$\mathrm{NaClO}$} & \multirow{4}{*}{4} & 0 & 0.8342 & $1.8 \times 10^{6}$ \\
\cline { 3 - 5 } & & 2 & $/$ & $3 \times 10^{5}$ \\
\cline { 3 - 5 } & & 24 & 0 & 1 \\
\cline { 3 - 5 } & & $\begin{array}{c}24(\text { biocide is added } \\
\text { again) }\end{array}$ & 0.8342 & 1 \\
\cline { 3 - 5 } & & 48 & & \\
\hline
\end{tabular}

\begin{tabular}{|c|c|c|c|c|}
\hline \multirow{5}{*}{$\mathrm{NaClO}$} & \multirow{5}{*}{8} & 0 & 2.5025 & $1.8 \times 10^{6}$ \\
\hline & & 2 & 1 & $2 \times 10^{5}$ \\
\hline & & 24 & 0 & 1 \\
\hline & & $\begin{array}{c}\text { 24(biocide is added } \\
\text { again) }\end{array}$ & 3.7537 & $8 \times 10^{5}$ \\
\hline & & 48 & 0 & 1 \\
\hline \multirow{10}{*}{$\begin{array}{l}\text { Benzalkonium } \\
\text { bromide }\end{array}$} & \multirow{5}{*}{1.25} & 0 & 1 & $1.8 \times 10^{6}$ \\
\hline & & 2 & 1 & $4 \times 10^{5}$ \\
\hline & & 24 & 1 & 1 \\
\hline & & $\begin{array}{c}\text { 24(biocide is added } \\
\text { again) }\end{array}$ & I & $4 \times 10^{5}$ \\
\hline & & 48 & 1 & 1 \\
\hline & \multirow{5}{*}{2.5} & 0 & 1 & $1.8 \times 10^{6}$ \\
\hline & & 2 & 1 & $2 \times 10^{5}$ \\
\hline & & 24 & 1 & 1 \\
\hline & & $\begin{array}{c}\text { 24(biocide is added } \\
\text { again) }\end{array}$ & I & $2 \times 10^{5}$ \\
\hline & & 48 & 1 & 1 \\
\hline
\end{tabular}

Table 3. The killing effect of sodium hypochlorite with $8 \mathrm{mg} / \mathrm{L}$ or benzalkonium bromide with $5 \mathrm{mg} / \mathrm{L}$ added in the seawater for $2 \mathrm{~h}$

\begin{tabular}{|c|c|c|}
\hline Water sample & \multicolumn{2}{|c|}{ Bacterium number $/ \mathrm{mL}$} \\
\hline Seawater (blank) & $1.5 \times 10^{6}$ & $1.7 \times 10^{6}$ \\
\hline Seawater $+\mathrm{NaClO}(8 \mathrm{mg} / \mathrm{L})$ & $4 \times 10^{5}$ & $4 \times 10^{5}$ \\
\hline Seawater + benzalkonium bromide $(5 \mathrm{mg} / \mathrm{L})$ & $2 \times 10^{5}$ & $2 \times 10^{5}$ \\
\hline
\end{tabular}

As shown in table 2 and table 3, the killing effect of sodium hypochlorite with $4 \mathrm{mg} / \mathrm{L}$ or $8 \mathrm{mg} / \mathrm{L}$ and benzalkonium bromide with $1.25 \mathrm{mg} / \mathrm{L}, 2.5 \mathrm{mg} / \mathrm{L}$ and $5 \mathrm{mg} / \mathrm{L}$ added in the seawater for $2 \mathrm{~h}$ is good.

\section{The Compatibility of Sodium Hypochlorite and Benzalkonium Bromide with the Scale Inhibitor}

Because there are the scale inhibitor $(6.25 \mathrm{mg} / \mathrm{L}$ PESA $+6.25 \mathrm{mg} / \mathrm{L}$ HPMA) and $50 \mathrm{mg} / \mathrm{L} 5 \%$ benzalkonium bromide (amount to $5 \mathrm{mg} / \mathrm{L}$ benzalkonium bromide) included in the corrosion inhibitor formulation, when the scale inhibiting effect of the corrosion inhibitor formulation in the seawater is tested, the compatibility of benzalkonium bromide with the scale inhibitor is tested. The scale inhibiting effect of the corrosion inhibitor formulation with $8 \mathrm{mg} / \mathrm{L} \mathrm{NaClO}$ added in the seawater is tested. All the test results are shown in table 4.

As shown in table 4 , the scale inhibiting effect of the scale inhibitor $(6.25 \mathrm{mg} / \mathrm{L}$ PESA $+6.25 \mathrm{mg} / \mathrm{L}$ HPMA) in the seawater is not effected by sodium hypochlorite or benzalkonium bromide, namely sodium hypochlorite or benzalkonium bromide are compatible with the scale inhibitor $(6.25 \mathrm{mg} / \mathrm{L}$ PESA +6.25mg/L HPMA). 
Table 4. The scale inhibition effect of the corrosion inhibitor formulation with scale inhibitor (PESA6.25mg/L+HPMA6.25mg/L) in the seawater when sodium hypochlorite or benzalkonium bromide is added

\begin{tabular}{|c|c|c|c|c|c|c|c|}
\hline \multirow[b]{2}{*}{ Test medium } & \multicolumn{5}{|c|}{ Concentration multiple } & \multirow[b]{2}{*}{$\Delta \mathrm{A}$} & \multirow{2}{*}{$\begin{array}{c}\text { Test } \\
\text { phenome-non }\end{array}$} \\
\hline & $\begin{array}{l}\text { Expres- } \\
\text { sed by } \\
\text { volume }\end{array}$ & $\begin{array}{c}\text { Expressed } \\
\text { by calcium } \\
\text { hardness }\end{array}$ & $\begin{array}{l}\text { Expressed } \\
\text { by total } \\
\text { hardness }\end{array}$ & $\begin{array}{l}\text { Expre } \\
\text {-ssed } \\
\text { by } \mathrm{Cl}^{-}\end{array}$ & $\begin{array}{l}\text { Express- } \\
\text { ed by } \\
\text { alkalinity }\end{array}$ & & \\
\hline Seawater (blank) & 2.48 & 2.52 & 2.43 & 2.52 & 1.63 & 0.89 & $\begin{array}{c}\text { Seawater } \\
\text { cloudy } \\
\text { and white } \\
\text { scale formed }\end{array}$ \\
\hline $\begin{array}{c}\text { Seawater }+ \text { scale } \\
\text { inhibitor } \\
(\text { PESA6.25mg/L+HP } \\
\text { MA } 6.25 \mathrm{mg} / \mathrm{L})\end{array}$ & 2.5 & 2.42 & 2.50 & 2.48 & 2.43 & 0.05 & $\begin{array}{c}\text { Seawater } \\
\text { transpare-nt }\end{array}$ \\
\hline $\begin{array}{c}\text { Seawater }+ \text { the } \\
\text { corrosion inhibitor } \\
\text { formulation with scale } \\
\text { inhibitor }(6.25 \mathrm{mg} / \mathrm{L} \\
\text { PESA }+6.25 \mathrm{mg} / \mathrm{L} \\
\text { HPMA) and } 2.5 \mathrm{mg} / \mathrm{L} \\
\text { benzalko- nium } \\
\text { bromide }\end{array}$ & 2.31 & 2.52 & 2.43 & 2.52 & 3.05 & -0.54 & $\begin{array}{c}\text { Seawater } \\
\text { transparent }\end{array}$ \\
\hline $\begin{array}{c}\text { Seawater }+ \text { the } \\
\text { corrosion inhibitor } \\
\text { formulation with scale } \\
\text { inhibitor }(6.25 \mathrm{mg} / \mathrm{L} \\
\text { PESA }+6.25 \mathrm{mg} / \mathrm{L} \\
\text { HPMA }) \text { and } 2.5 \mathrm{mg} / \mathrm{L} \\
\text { benzalkoni- um } \\
\text { bromide }+8 \mathrm{mg} / \mathrm{L} \\
\mathrm{NaClO}\end{array}$ & 2.31 & 2.34 & 2.23 & 2.28 & 2.27 & 0.01 & $\begin{array}{c}\text { Seawater } \\
\text { transpare -nt } \\
\text { with few scum } \\
\text { and } \\
\text { adherentcrysta } \\
\text { lline grain }\end{array}$ \\
\hline
\end{tabular}

(Notes: $\triangle \mathrm{A}$ is the difference between concentration multiple expressed by $\mathrm{Cl}^{-}$and expressed by alkalinity)

\section{The Compatibility of Sodium Hypochlorite and Benzalkonium Bromide with the Corrosion Inhibitor}

Because there is $50 \mathrm{mg} / \mathrm{L} 5 \%$ benzalkonium bromide (amount to $5 \mathrm{mg} / \mathrm{L}$ benzalkonium bromide) included in the corrosion inhibitor formulation, benzalkonium bromide is not only biocide but also corrosion inhibitor component, namely the biocide benzalkonium bromide is compatible with the corrosion inhibitor formulation. In order to research further the compatibility of sodium hypochlorite and benzalkonium bromide with the corrosion inhibitor, the inhibition effect to carbon steel of the corrosion inhibitor formulation with $\mathrm{NaClO}$ or benzalkonium bromide added in the seawater is tested, and the test result is shown in table 5.

As shown in table 5, when the biocide sodium hypochlorite or benzalkonium bromide is added in the seawater, the inhibition effect of the corrosion inhibitor formulation to Q235 carbon steel in the seawater isn't affected by them, namely the biocide sodium hypochlorite or benzalkonium bromide is compatible with the corrosion inhibitor formulation. 
Table 5. The inhibition effect of the corrosion inhibitor formulation to Q235 carbon steel in the seawater when sodium hypochlorite or benzalkonium bromide is added $\left(50^{\circ} \mathrm{C}, 72 \mathrm{~h}\right)$

\begin{tabular}{|c|c|c|c|c|c|c|c|}
\hline Test medium & No. & $\begin{array}{c}\mathrm{S} \\
\left(\mathrm{cm}^{2}\right)\end{array}$ & $\mathrm{m}_{1}(\mathrm{~g})$ & $\mathrm{m}_{2}(\mathrm{~g})$ & $\begin{array}{c}\Delta \mathrm{m} \\
(\mathrm{mg})\end{array}$ & $\begin{array}{c}\mathrm{V}^{-} \\
\left(\mathrm{g} / \mathrm{m}^{2} \cdot \mathrm{h}\right)\end{array}$ & $\begin{array}{c}\mathrm{V}_{\mathrm{h}} \\
(\mathrm{mm} / \mathrm{a})\end{array}$ \\
\hline \multirow{2}{*}{$\begin{array}{l}\text { Seawater concentrated } 2 \\
\text { times }+ \text { the corrosion } \\
\text { inhibitor formulation }\end{array}$} & \#6 & 25.589 & 11.6725 & 11.6601 & 12.4 & 0.0673 & 0.0746 \\
\hline & $\# 7$ & 26.319 & 13.6820 & 13.6699 & 12.1 & 0.0639 & 0.0708 \\
\hline \multirow{2}{*}{$\begin{array}{l}\text { Seawater concentrated } 2 \\
\text { times }+ \text { the corrosion } \\
\text { inhibitor formulation } \\
+8 \mathrm{mg} / \mathrm{L} \mathrm{NaClO}\end{array}$} & $\# 8$ & 26.286 & 14.2819 & 14.2699 & 12.0 & 0.0634 & 0.0703 \\
\hline & $\# 9$ & 26.019 & 14.5669 & 14.5546 & 12.3 & 0.0657 & 0.0728 \\
\hline \multirow{2}{*}{$\begin{array}{l}\text { Seawater concentrated } 2 \\
\text { times }+ \text { the corrosion } \\
\text { inhibitor formulation } \\
+100 \mathrm{mg} / \mathrm{L} 5 \% \\
\text { benzalkonium bromide }\end{array}$} & \#14 & 26.748 & 14.6745 & 14.6624 & 12.1 & 0.0628 & 0.0697 \\
\hline & $\# 16$ & 26.815 & 15.6198 & 15.6073 & 12.5 & 0.0647 & 0.0718 \\
\hline
\end{tabular}

(Notes: No.-Specimen number, S-surface area, $\mathrm{m}_{1}$-the mass of the specimen before it is immersed in the test medium, $\mathrm{m}_{2}$-the mass of the specimen after it is taken out from the immersed test medium and cleaned by acid, $\Delta \mathrm{m}=\mathrm{m}_{2^{-}} \mathrm{m}_{1}, \mathrm{~V}^{-}$- corrosion rate expressed by mass change, $\mathrm{V}_{\mathrm{h}}$ - corrosion rate expressed by variation in thickness)

\section{Conclusions}

Sodium hypochlorite and benzalkonium bromide have good killing effect. Sodium hypochlorite or benzalkonium bromide is not only compatible with a scale inhibitor, also compatible with a corrosion inhibitor formulation.

\section{References}

[1] Bao Yanjun. Study on manner of dosing for circulating cooling water system in Zhuhai Power Station. Guangdong Electric Power.2006 Vol.19 No.10: 22-25.

[2] Chen Haiyan, Lin Zhenlong, Chen Pimao, Qin Chuanxin, Tang Zhenzhao, Yu Jing. Electrochemical corrosion bechavior of copper in marine microbial medium. Journal of materials engineering. No. 7(2014):22-27.

[3] Ji Xiaohui, Lin Jianzhong. The Study on The Treatment Method of Circulating Cooling Water System of The Sea Water Cooling Tower. Guangdong Chemical Industry.2010 Vol.37 No.5: 184-186, 190.

[4] Zhang Yuzhong, Peng Xiaomin. Treatment technology of seawater as circuating cooling water. Industrial water treatment. 2004 Vol.24 No.8: 14-17.

[5] Wang Guangzhu, Li Chengrong, Zhou Jinde, Luo Jianghe, Wang Deliang, Fan Kun, Ding Jianhe, Ren Qingjie, Chen Baoqi, Huang Xiaozhong. Study on sea water circulatory cooling technology and present state of its application. Thermal Power generation. 2007(11): 68-71.

[6] Chen Jun, Wang Jianzhang, Yan Fenyuan, Zhang Qing, Li Quanan. Corrosion wear synergistic behavior of Hastelloy C276 alloy in artificial seawater. Trans. Nonferrous Met. Soc. China 25(2015): 661-668.

[7] Hou Chunyang, Wu Jie, Zhao Nan, Wu Yunfang, Liu Shujing, Wang Weizhen. Corrosion control, fouling deposit control and biofouling control in the seawater circulating cooling system. Ocean technology. 2002 Vol.21 No.4: 46-50.

[8] Niu Yan, Lin Zhen long, Lin Guoji, Fang Yanxiong, Chen Haiyan, Chen Pimao, Yu Jing. Research on corrosion behavior of Q235 steel in marine iron- oxidizing bacteria. Marine environmental science. Vol.33, No. 5(2014):739-744. 
[9] Liu Jin, Liu Zheng, Xie Siwei, Liu Baoyu. Study on corrosion performance of carbon steel in seawater with corrosion inhibitor of compounding schiff base. Marine Sciences.Vol.38, No. 5(2014): 16-23.

[10] Fan Xiaomei. How to deal with cooling water in littoral power plants. Journal of Chongqing Electric Power College.2006 Vol.11 No.4: 22-24.

[11] Cai Guowei, Yang Lihui, Li Yantao, Chu Tonglin. Research and development of corrosion Inhibitiors for carbon steel in Seawater. Corrosion \& Protection. Vol. 36, No. 2(2015): 101-107.

[12] Tang Dongsheng. Selection of Treatment Options for Sea Water Circulating Cooling Water. Electric Power Construction.2003 Vol.24 No.5: 12-14.

[13] Guo Zhaogeng. The water treatment method optimization of the circulating cooling system used Yellow sea seawater as cooling water. Silicon Valley.2012 No.20: 118-119. 